\title{
SHELTON COLLEGE AND STATE LICENSING OF RELIGIOUS SCHOOLS: AN EDUCATOR'S VIEW OF THE INTERFACE BETWEEN THE ESTABLISHMENT AND FREE EXERCISE CLAUSES
}

\author{
RUSSELL KIRK* \\ I \\ INTRODUCTION
}

Near to the breakwater at the faded old seaside resort of Cape May, New Jersey, there looms an immense hotel of the twenties-formerly the fashionable Admiral Hotel, now called the Christian Admiral. Today it is the property of a small fundamentalist denomination, the Bible Presbyterian Church. To the rear of the hotel stand the new buildings of Shelton College, a Bible Presbyterian school for educating preachers and teachers--something of a seminary, something of a liberal arts college.

The state of New Jersey has tried to prevent Shelton College from operating within the state; but this attempt has been rebuffed, at least for the time being, by a federal court ruling. 'Persistently, the state of New Jersey has also tried to prevent Shelton College from conferring degrees; here a federal court decision has sustained Shelton College again, at least for the time being. ${ }^{2}$ Whether Shelton can function fully as a school of higher studies, or survive at all, will probably be decided judicially within a few months.

This interesting case is intimately connected with the developing law of churchstate contacts, including the entanglement test announced for the Establishment Clause by the Supreme Court. ${ }^{3}$ As such the case raises again long-debated questions of relationships between church and state in America. The principal issue in the Shelton College case is this: how far may state agencies regulate "pervasively religious" educational institutions? May a state forbid a college or school to exist unless it complies with state requirements and regulations repugnant to that educational institution's sponsoring religious body? Or, if such a college or school is

\footnotetext{
Copyright $(1981$ by Duke University

* Director, social-science program, Educational Research Council of America; editor, The UniverSITY BoOKMAN.

1. 482 F. Supp. 968 (D.N.J. 1980), aff'd, Slip Opinion, 3d Cir. (Apr. 14, 1981).

2. Shelton College v. State Board of Education, 48 N.J. 501, 227 A.2d 612 (1967); New JerseyPhiladelphia Presbytery of the Bible Presbyterian Church v. New Jersey State Board of Higher Education, No. 79-3341 (D.N.J., May 18, 1981).

3. Another article in this issue, Tangling with Entanglement; Toward a Constitutional Evaluation of Church-State Contacts by James Serritella, 44:2 LAW \& ConT Prob. Spring 1981, reviews the specific course in the approximately ten-year history of the entanglement test in the Supreme Court and in the lower courts.
} 
permitted to continue to teach, may a state's agencies nevertheless prohibit the granting of degrees or certificates, and even the use of the term "college"?

Church-state relationships as they impinge on educational institutions have, of course, been scrutinized by courts outside New Jersey. Similar issues are involved, for instance, in attempts of the Internal Revenue Service to remove the taxexemptions of Christian schools not complying with "affirmative action" policies and the like. ${ }^{4}$ During the past decade, courts have tended to protect the claims of religious groups against the claims of agencies of the federal and state governments, especially where free exercise has outweighed entanglement danger. Such decisions have exempted Amish children from having to attend public schools; ${ }^{5}$ have relieved Christian schools in Ohio, Kentucky, and other states from much regulation by state departments of public instruction; ${ }^{6}$ have prevented the National Labor Relations Board from ordering collective-bargaining elections in Catholic schools $;{ }^{7}$ have found unconstitutional the imposition of federal-state unemployment compensation programs upon schools conducted by Christian denominations. ${ }^{8}$ The court decisions are neither conclusively nor uniformly protective, however. Some such cases have been appealed, and somewhat similar cases remain contested in various courts.

It does not necessarily follow that the cited instances of relative immunities for church-related institutions will be extended by American courts. Many of the sheltering decisions mentioned above followed naturally enough from the Supreme Court's "entanglement" test, introduced by Chief Justice Burger, ${ }^{9}$ but soon taken up by some of his colleagues with a zeal far exceeding his own. The Burger Court had also to harmonize its approach with two Supreme Court decisions on the permissibility of certain state allowances made for religion in the schools. In Everson v. Board of Education, ${ }^{10}$ the Court had upheld state reimbursements to parents of parochial-school children who used public buses. A few years later, in Zorach v. Clauson, " a state "released time" program was upheld, where the religious training of the students occurred off public premises.

The Court rulings, especially after 1970 and 1971, found various state programs unconstitutional as too entangling: supplementation of teachers' salaries in religious schools for those teachers giving secular courses; ${ }^{12}$ reimbursements for the

4. See a useful recent pamphlet by P. Skerry, Christian Schools, Racial Quotas, and The IRS (Ethics and Public Policy Reprint 28) (1980). Other cases on state regulation of religious schools are cited in Part IV of this article.

5. Wisconsin v. Yoder, 406 U.S. 205 (1972).

6. See the cases discussed in Part IV below.

7. NLRB v. Catholic Bishop of Chicago, 440 U.S. 490 (1979).

8. Grace Brethren Church v. California, No. CV 79-93MRP (C.D. Cal. Sept. 21, 1979). Durso \& Brice, NLRB v. the Catholic Bishop of Chicago: Government Regulation Versus First Amendment Religious Freedoms, 24 ST. Lovis U.L. Rev. 295, 325 n. 137 (1980), list four additional such cases in other states, as well as three cases in which state officers held that state unemployment compensation schemes did not apply to religious schools. All these cases are cited by Serritella, supra note 3, at text to notes 52-53.

9. Lemon v. Kurtzman, 403 U.S. 602 (1970). For an extensive discussion of the Lemon test, see Serritella, supra note 3 .

10. 330 U.S. 1 (1947).

11. 343 U.S. 306 (1952).

12. Lemon v. Kurtzman, 403 U.S. 602 (1970). 
costs of entire "packages" (salaries, textbooks, instructional materials) in secular subjects; ${ }^{13}$ direct loans of instructional materials such as maps and equipment; ${ }^{14}$ auxiliary educational state services provided on non-public campuses; ${ }^{15}$ field trip transportation costs of parochial school students; ${ }^{16}$ state testing services when the tests are prepared by the parochial school; ${ }^{17}$ and maintenance and repair of sectarian schools, tuition costs paid to parents of parochial-school students, and tuition tax credits for such parents. ${ }^{18}$ These denials were based upon the principle that so to indulge "pervasively religious" schools would bring on the peril of entangling church affairs and political concerns-with the possible subordination of church to state.

Other types of state assistance to sectarian schools have been upheld on the basis that they did not involve excessive entanglement: loans of secular textbooks to parochial school children $;^{19}$ costs of administering mandatory tests prepared by the state; ${ }^{20}$ diagnostic health services provided on religious campuses; ${ }^{21}$ therapeutic health and education services provided to sectarian students off the religious campus; $;^{22}$ possibly, all health services and public lunch programs for parochial school students on their campuses; ${ }^{23}$ federal construction grants to church-related institutions of higher learning; ${ }^{24}$ and state revenue bonds to finance construction on campuses of non-public colleges. ${ }^{25}$

The neutrality principle, if consistently applied, would touch benefits as well as burdens. It seems to follow logically that if religious schools are to be denied benefits from the state, then in justice they ought to be exempted from various forms of state control which are prescribed for state-financed, state-operated public schools. The logical converse of no entanglement in funding is no entanglement in direction.

Court entanglement decisions in recent years can be said, under this view, not to have advanced the cause of church-related schools so much as they have halted encroachments by the state. Converse restraints upon state government control over religious schools have seemed the fair counterpart-the logical reverse pole of the neutrality principle-to court restraint upon state government assistance to religious schools. The present question is whether extension of the entanglement doctrine will lead to virtual immunity of religious schools from federal and state supervi-

13. Id.

14. Meek v. Pittenger, 421 U.S. 349 (1974).

15. Id. In Meek state health services were also invalidated, but only because that portion of the statute was deemed inseparable from the invalid remainder.

16. Wolman v. Walter, 433 U.S. 229 (1977).

17. Levitt v. Committee for Public Education, 413 U.S. 472 (1973).

18. Committee for Public Education \& Religious Liberty v. Nyquist, 413 U.S. 756 (1973).

19. Board of Education v. Allen, 392 U.S. 236 (1968).

20. Wolman v. Walter, 433 U.S. 229 (1977); Committee for Public Education \& Religious Liberty v. Regan, - U.S. - 100 S. Ct. 840 (1980).

21. Wolman v. Walter, 433 U.S. 229 (1977).

22. Id.

23. Lemon v. Kurtzman, 403 U.S. 602 (1970), in dicta.

24. Tilton v. Richardson, 403 U.S. 672 (1971).

25. Hunt v. McNair, 413 U.S. 734 (1973). 
sion. That may be determined by the Shelton College rulings and other significant current contests.

To put the matter another way, does a "compelling state interest" justify state agencies in licensing, regulating, and taxing church-related educational institutions, notwithstanding the provisions of the Establishment Clause of the First Amendment and other constitutional guarantees? Or are "pervasively religious" institutions entitled constitutionally to determine their own standards and conduct their own studies, without intervention from the political state? The Shelton College case is a convenient model or instrument for examining these large questions.

In successive sections of this article, then, we outline the background of the Shelton College controversy; follow its course in state and federal courts; and conclude with some discussion of the motives and scope of governmental intervention in church-related colleges and schools. Will the entanglement doctrine operate more as a restraint upon churches than as a restraint upon government? Will all types of schooling tend to be assimilated into uniform state-prescribed patterns? Will public policy come to override, generally, the exemptions, immunities, and autonomy of American church-schools and churches? Shelton College's resistance to the New Jersey Board of Higher Education bears upon these issues and possibilities.

\section{II}

\section{Shelton College's Tribulations ${ }^{26}$}

Shelton College does not seem outwardly an object calculated to incur the hostility of the state of New Jersey. It has fewer than thirty students at present (and all but one or two of those are members of the Bible Presybyterian Church), a mild-mannered and well-schooled president, and a faculty that serves competently for very small pay. Through its preceding incarnations as the National Bible

26. The tribulations of Shelton College reach back to a court case decided in 1967 . The chronology which frames the discussion in this article is as follows:

1967 - New Jersey Supreme Court holds that Shelton College cannot confer baccalaureate degrees unless the College is licensed by the state. Shelton College v. State Board of Education, 48 N.J. 501,226 A.2d 612 (1967);

1971 - Shelton College begins operation in Cape Canaveral, Florida;

Feb., 1979-Shelton College submits an application to the N.J. State Board of Higher Education seeking a license to grant degrees in New Jersey;

Fall, 1979-Shelton commences teaching, without a license, in Cape May, N.J., with the intent that degrees would be granted to students through the Florida campus;

Nov. 15, 1979--complaint filed by the State Board in Chancery Division, Supreme Court of N.J. TRO entered by the Court, restraining all educational or instructional activities at the College. Excepted from the order was instruction for students then attending the College, until the end of the academic semester;

Nov., 1979-the College, the sponsoring Church, teachers, students, and parents of students file a motion for a TRO in federal district court, seeking to stay the state court proceeding;

- TRO denied, but hearing is set for preliminary injunction;

- State court issues a preliminary injunction continuing the prohibitions contained in the TRO; - hearing held on preliminary injunction in federal district court.

Jan. 4, 1980-U.S. District Court-Judge Dickinson R. Debevoise renders an opinion which upholds the right of Shelton College to continue teaching, advertising, and granting credits. The district court abstains from deciding a single issue: may the state require the College to subject itself to licensing as a condition of the College's right to award baccalaureate degrees? 
Institute and the Union Missionary Training Institute, Shelton College traces its continuity back to 1885; some of the books in its library come down from those beginnings elsewhere. Undoubtedly Shelton is one of those educational institutions which are described as "pervasively religious"; for the College's catalogue declares its attachment to "That theology . . . commonly known as the historic Reformed faith or Calvinistic doctrine ... articulated in the Westminster Confession of Faith. ... The purpose of the College is summarized in the motto proclaimed by the founder, 'Training Christian Warriors.,"'27

The core curriculum at Shelton College consists of three courses in the Bible, two in communication, two in humanities, two in mathematics and science, one in history, and one in political science. Majors are offered in Biblical literature, elementary education, English, history, music education, and business administration. The study of classical languages is encouraged and is being expanded. It becomes clear to anyone who visits the Cape May campus that the professors and students are devout members of their denomination and are strongly attached to their College. Shelton does not seek to enroll young people from other denominations, although it will accept qualified applicants who subscribe to the Apostles' Creed and abide by the College's regulations and standards.

In fact, Shelton is not very different from the Harvard or Yale of an earlier time; certainly Shelton conforms to the familiar pattern of the church-related denominational college in America, with its ministerial guidance and its rural setting. Shelton may be oldfangled, but Shelton is no fraud: it has the limitations and the virtues of its educational type. Why, then, has it been chosen by the New Jersey Board of Higher Education for expulsion or reduction? The formal charge is that Shelton has not obtained a license from the Board. Therefore the State Board of Higher Education sought and obtained in 1979 from the New Jersey Superior Court a preliminary injunction restraining Shelton College, its directors and officers

Feb., 1980-the state appeals the district court decision (granting the preliminary injunction to the College) to the 3rd Circuit Court of Appeals;

June 30-July 1, 1980-trial in Chancery Division of N.J. Superior Court, Cape May County (Atlantic City) N.J., on the issue of the constitutionality of state licensing as a prerequisite to the granting of the BA degree, as applied to Shelton College;

Oct. 16, 1980-oral argument in the 3rd Circuit Court of Appeals;

Nov. 10, 1980-opinion rendered by state court, upholding the licensing power of the state;

Dec. 10, 1980-order entered by N.J. Superior Court, enjoining Shelton College from awarding baccalaureate degrees without a license from the State Board of Higher Education;

Jan. 20, 1981-state court proceeding is appealed to N.J. Superior Court, Appellate Division;

April 14, 1981-decision of 3d Circuit Court of Appeals, affirming the district court insofar as the constitutional liberties of the College are involved, the right of the College to award credits, and the right to award degrees through the College's Fla. campus. The Court of Appeals also affirms the district court's decision re abstention on the issue of the right to grant degrees, but notes that the district court maintains continuing jurisdiction over the case for consideration of applications for interim relief.

May 18, 1981-decision in U.S. District Court, by Judge Debevoise, granting preliminary injunction against enforcement of N.J. Superior Court order of Dec. 10, 1980; Shelton College to be permitted to award degrees until N.J. Supreme Court should construe applicable statutes and regulations.

27. Shelton College Catalogue, 1980-81, at 9. 
from engaging in advertising, assisting in or causing the offering of any courses or classes of instruction, or engaging in any form of educational instruction . . . except for presently enrolled students until the conclusion of the academic semester on December 22, 1979, unless a license for same is issued by the New Jersey Department of Higher Education. . . . ${ }^{28}$

And why won't Shelton seek a license? Because Shelton's directors, and the Bible Presbyterian Church, fear with reason that submission to licensing would bring state control over the College; and that such control would be exercised in ways repugnant, in the phrases of the College catalog, to "a liberal arts college . . . operated in harmony with conservative American principles and the historical Christian conviction that the Bible is the Word of God. . ."29 Shelton College did not desire to be licensed by that Department, for submission to licensing would bring permanent submission to state specifications and controls. Even had the College's directors applied for a license, it seemed improbable that such a license would have been issued. The College's response to the Board led to the series of Court actions which continue to the present writing. The College functions today, though with Damocles' sword suspended above it.

Probably there is more to the state's repeated actions against Shelton than the matter of this license. A question of personality may be perceived in the background - the personality of Dr. Carl McIntire, chancellor of Shelton College and chairman of its board. Dr. McIntire often has been described in the popular press as an "ultra-conservative." $\mathrm{He}$ is a powerful fundamentalist preacher, not kindly of tongue toward those who differ with him. His attitudes on various subjects are very like those of Orangemen in the north of Ireland. He has been candidly hostile to Popery: "remember, remember, the Fifth of November." New Jersey is a state where Roman Catholics are very numerous; and New Jersey's public educational institutions are said to have been sensitive to presumed Catholic opinion on a number of occasions. The outspoken Dr. McIntire, over his long public career, seems to have made more enemies than friends.

In the litigation concerning Shelton, the office of New Jersey's attorney-general has not succeeded in bringing Dr. McIntire to the stand. But a hint of the state's dislike of him hangs over the proceedings. Dr. McIntire's troubles with the state of New Jersey go back to the fifties, when Shelton College was situated at Ridgewood, New Jersey, across the Hudson from New York City. Dr. McIntire relocated the College at Cape May; in 1965, the state commenced action against Shelton for not being licensed. In 1967, having lost in the courts, ${ }^{30}$ Shelton College retreated to Cape Canaveral, Florida. But in the autumn of 1979, the Shelton campus at Cape May was reopened; and the New Jersey Board of Higher Education, acting through the attorney-general, promptly instituted suit to enjoin Shelton's operation. So commenced the complex continuing New Jersey State Board of Higher Education v. Shelton College.

28. Superior Court of New Jersey, Chancery Division, Cape May Court, Docket No. C-1088-79E, Nov. 15, 1979.

29. Shelton College Catalogue, 1980-81, at 10.

30. Shelton College v. State Board of Education, 48 N.J. 501, 227 A.2d 612 (1967). 
Shelton College, on principle, does not accept public funds from local, state, or federal treasuries. Watchbirds, public and private, seem to be vigilantly monitoring Dr. McIntire and his undertakings. The Bible Presbyterian Church's hostel, the hulking Christian Admiral by the breakwater, does not now enjoy tax exemption. The Church incautiously permitted some members of the Audubon Society to stay there while they watched birds on the beach; and the Internal Revenue Service promptly cancelled the Christian Admiral's tax exemption, on the ground that the building was not being used exclusively for religious purposes. (Had the Bible Presbyterians been less orthodox, perhaps they might have argued that Audubon Society people are devout pantheists.) The College is recognized as an educational institution by the federal Veterans' Administration, the Immigration and Naturalization Service, and the Social Security Administration; it is licensed at Cape Canaveral by the Florida State Board of Independent Colleges and Universities; and it is affiliated with the International Council of Christian Churches, a fundamentalist association.

The state of New Jersey has probably the strictest statutes regulating "private" or "independent" colleges of any state in the Union. As this is put by William B. Ball, lawyer for Shelton College in this case:

The New Jersey statutes are remarkable, in that they vest total control of higher education in the State, and they even consider all private colleges to be part of a state 'system' of higher education. Further, the regulations which the State Board of Higher Education have published implement the total control of the State. These are really absurd-but very dangerous. Throughout these regulations there appears repeatedly wording such as 'staff shall be sufficient,' 'teaching backgrounds must be adequate,' 'the program of the college must be appropriate in terms of its stated purposes.' While all of these sound innocuous, we then find that there is a definitional section in the regulations which states that the meaning of 'sufficient', 'adequate', 'appropriate', etc., shall be determined by-guess who? - the State Board of Higher Education. ${ }^{31}$

The New Jersey statutes provide that every private or independent college within the state must be licensed by that same State Board. ${ }^{32}$ These licenses are periodically reviewed, and then renewed or revoked. (The older New Jersey universities and colleges, including Princeton and Rutgers, are exempted from this inquisition under a "grandfather" clause. $)^{33}$ In other respects as well, the power of the State Board of Higher Education over non-public colleges appears to be arbitrary and in practice little limited.

What with its history of difficulties with the state of New Jersey, and its chancellor's unpopularity in several quarters, it seemed in the autumn of 1979 that Shelton College was in for a very thin time. The Bible Christian Church is a very small denomination indeed, and far from rich; the costs of a legal contest with the state of New Jersey are very large. But the College did not give way.

31. Letter of W. B. Ball to author.

32. N.J. Stat, ANn. 18A: 68-6 (West 1968).

33. Id. 
III

Free to Teach but not to Flourish: Free Speech AND FreE EXercise Issues?

As already reviewed above, the 1979 state court injunction against Shelton College was based on the New Jersey statutes, without regard to constitutional questions. There was precedent for such a course: in 1967, during the earlier litigation between the Board of Education and Shelton College, the Supreme Court of New Jersey had ruled that the New Jersey licensing scheme for colleges was constitutional. $^{34}$ But that earlier case had paid little attention to the issue of religious liberty.

Had the Superior Court's preliminary injunction gone into full effect, the religious mission of Shelton would have been seriously interrupted; and the small student body of the College might have disappeared altogether after the Thanksgiving recess. At this point, Shelton College engaged William Ball to defend its interests. Ball, a specialist in church-state cases, had won the case of the Amish children, Wisconsin $v$. Yoder ${ }^{35}$ before the Supreme Court.

Ball swiftly brought an action in the federal district court against the New Jersey Board of Higher Education and related New Jersey officials responsible for the action against Shelton College. ${ }^{36}$ On December 14, Judge Dickinson R. Debevoise granted an injunction in favor of the college. He found that the College was entirely religious in character, and so possessed the right to teach and to advertise. But, perhaps troubled by this federal intervention in what had been a state case, Judge Debevoise returned to the New Jersey Superior Court the determination of whether Shelton College might award degrees. This led to the litigation which is still pending. More specifically, it was left to the state court to determine whether the state's interest in "the integrity of the bachelor's degree" is outweighed by the College's interest in protecting its religious and educational liberties.

Judge Debevoise's opinion appears to have been the first decision by a federal court to the effect that a college, if pervasively and genuinely religious, enjoys under the First Amendment a right to teach, solicit students, and advertise. His opinion called New Jersey's denial of the right to teach a violation of the religious liberty of Shelton College. It should be noted that this opinion is restricted to colleges still possessed of a dominant church relationship; it does not cover substantially secularized educational institutions.

This was a heartening victory for Shelton; but it returned the case, in part, to the state court. In Count I of the College's complaint to the federal court, Ball had objected to the delegation of "blanket authority" to the Board of Higher Education:

The statutes leave wholly to the uncontrolled discretion of the Board of Higher Education, for its approval, the determination whether the College, as a religious

34. Shelton College v. State Board of Education, 48 N.J. 501, 227 A.2d 612 (1967).

35. Wisconsin v. Yoder, 406 U.S. 205 (1972).

36. 482 F. Supp. 968 (D.N.J. 1980), aff'd, Slip Opinion, 3d Cir. (April 14, 1981). 
organization, may recognize the attainment or proficiency of any student who has chosen to participate in its program through giving each student a 'degree'. The regulations and standards cover eight (8) categories and are 47 in number, including subparts, and they cover every conceivable aspect of the life and activity of a private institution. Some of these controls are stated in language that is unconstitutionally vague. The statutory grants of power are in violation of the rights of the plaintiff churches and the College protected by the Due Process Clause of the United States. ${ }^{37}$

Both the attorney-general of New Jersey and Shelton College eventually appealed from Judge Debevoise's opinion to the U.S. Court of Appeals for the Third Circuit. The state appealed on the ground that New Jersey's "compelling interest" in public instruction must take precedence over the liberties of a church-related college. Shelton's lawyer, however (after Judge Gruccio's second adverse decision, months later), appealed the Debevoise ruling on the ground that the judge had erred in returning to the state court the essential issue of the integrity of the bachelor's degree. Ball argued the point before the Third Circuit on October 16, 1980. On April 14, 1981, the Third Circuit sustained the correctness of the federal district court's decision to grant a preliminary injunction and to abstain from deciding the issue of whether Shelton College could grant degrees.

As stated, the question of degree-granting was referred back to the Superior Court of New Jersey-indeed, to the very judge whose injunction against Shelton College had been overturned by the federal judge, and who was said by some observers to have resented that federal intervention. As matters were to turn out, the state judge chose not to change his mind about Shelton. ${ }^{38}$ Now Shelton College must endeavor to prove in a state court that the degrees Shelton College wished to grant to graduates, but had not yet begun to award-the degrees of bachelor of arts, bachelor of sacred music, bachelor of Christian education, bachelor of sacred Scripture - ought not be subject to a state educationist bureaucracy, whatever New Jersey's public concern for "the integrity of the bachelor's degree."

The argument that the state's concern for integrity of the bachelor's degree conceivably justifies a state agency in refusing to permit a religious school to grant degrees or to call itself a college, even though the school may continue to teach, has troubling practical implications. In present-day America, how could a little institution like Shelton attract students and therefore survive and do its work for the church, if it were not permitted to confer degrees or at least let its graduates say they had attended a real college? Again Shelton had to confront the unfriendly officials of the Board of Higher Education.

The Shelton case thus shifted back to Judge Gruccio's courtroom at Atlantic City, where I participated in the presentation of the College's case as expert witness. The dreary decayed streets around the courthouse seemed symbolic of a civilization already far gone toward centralization, secularism, and intellectual apa-

37. Verified Complaint for Temporary Restraining Order, Declaratory Judgment and Preliminary and Permanent Injunction, filed in Shelton College v. New Jersey State Board of Education (U.S. District Court for N.J., Nov, 19, 1979), at p. 12 ๆ 50.

38. Superior Court of New Jersey, Chancery Division, Cape May County, Docket No. C-1088-79E, Dec. $10,1980$. 
thy. Within the courtroom a good many Bible Presbyterians gathered during the trial early in July, 1980, prayerful, hopeful. Dr. McIntire did not appear.

The grand point at issue, in this new trial, was whether the state of New Jersey has a compelling interest in maintaining the integrity of the bachelor's degree; and if so, whether letting Shelton call itself a college and grant degrees would impair that vaunted integrity. Judge Gruccio, during the questioning, expressed his dissatisfaction with the standards of higher education.

My testimony on the stand was to the general effect that the bachelor's degree scarcely can be said to retain much integrity on the typical contemporary campus-it having been cheapened by the rapid quantitative expansion of student populations over the past quarter of a century. I offered examples of frivolous and meaningless degrees conferred by various colleges, including some in New Jersey. There is Centenary College, offering a degree in "equine science"-horsemanship; there is Edison State College, for external degrees, with no regular curriculum at all. What common standard for the bachelor's degree may be discerned among such diverse institutions as St. Thomas Aquinas College in California, Embry-Riddle Aeronautical University, Goddard College in Vermont (with its Intitute for Anthroposophical Studies, joining practical organic gardening to yoga exercises), and City College of New York? I suggested that the curriculum and the standards of little Shelton College, whatever its limitations, are sounder than those of many New Jersey institutions long licensed by the State Board. What compelling interest could the Board of Higher Education have in overseeing the workings of a little church school?

I departed before the day on which the attorney-general's expert witnesses testified; I am told that Judge Gruccio questioned them somewhat sharply. Ball filed a forty-nine-page brief on August 1. This civil action between the Board of Higher Education and Shelton College produced a defendants' brief by Ball as telling, it seems to me, as his famous brief in Wisconsin $v$. Yoder. In his treatment of the subject of forbidden entanglements between government and religious institutions, he summed up the more important Supreme Court decisions of recent years on this grave issue. ${ }^{39}$ Then he swept into the pith of his argument:

The imposition of the State's licensing system on Shelton College, as the condition precedent to its granting of the bachelor's degree, is an imposition of government-church entanglements prohibited under the First Amendment. The very justification for the statutes and regulations, as representing a compelling state interest, is found in their comprehensiveness and pervasiveness. The State's theory is that there is imminent and extraordinary public need for protection of the bachelor's degree; the licensing scheme, to meet so great a need, must be comprehensivethat is, in relation to any church entity, entangling. If the State now argues that its licensing scheme is really a mild affair, calling only for a little information-gathering, an occasional look-in, and some friendly advice, then the State destroys its argument of compelling state interest.

In fact, the statutes and regulations are, as applied to Shelton, entanglement itself. They do not merely contain 'some element of governmental evaluation and

39. Ball's discussion included Walz v. Tax Commission, 397 U.S. 664 (1970), Lemon v. Kurtzman, 403 U.S. 602 (1971), State of New York v. Cathedral Academy, 434 U.S. 125 (1977), and several other cases. 
standards', they bristle with it. . . The worst vice of entanglement - the thrusting of the State into the role of making, or influencing, religious determinations - is found in the New Jersey licensing-control system, whereby the State, as the State's witness, Suarez, frankly acknowledged, has the power to pass upon whether a religious institution is achieving its religious purposes. Even that vice, however, is exceeded by New Jersey's statutory provision that would pave Shelton into State's 'system' of higher education. . . . This is not mere 'entanglement'; it is envelopment. ${ }^{40}$

This powerful brief was of no immediate avail. Judge Gruccio did not hand down his opinion for more than two months; when it was finally announced, it went against Shelton College. ${ }^{41}$ Shelton is appealing in the New Jersey courts against the Superior Court decision; both sides have appealed some parts of the federal District Court decision of December, 1979, on different grounds, as mentioned above.

Shelton College won a round in this prolonged contest when, on May 18, 1981, Judge Debevoise ruled in federal district court that Shelton may continue to award degrees until the Supreme Court of New Jersey construes the applicable New Jersey statutes and regulations; he granted a preliminary injunction against enforcement of the Gruccio decision. ${ }^{42}$ The College plaintiffs were delighted at this reprieve. But William Ball remarked privately, "I expect this thing to go on like Jarndyce v. Jarndyce."

Thus none of the unsettling issues in the case is yet resolved: the protection for religious teaching against state education authorities; the question of whether the bachelor's degree retains any shred of integrity; the problem of how consuming an interest a state may have in church colleges; whether Shelton may grant degrees; the controversy about the practical limits of "entanglement" and about First Amendment free exercise and free speech values.

What then, is the significance of this prolonged litigation concerning a tiny stubborn denominational college? There is more in it than meets the impatient eye. The affair touches upon large concerns of freedom and diversity in the higher learning and upon the conceivable subordination of things spiritual to things temporal. Below I set down some reflections of this sort.

IV

\section{No Room for Religious Schools in the Secular City?}

The Shelton College case is a microcosm of the difficulties in which church colleges, schools, and related religious institutions have become involved in recent years. Consider the following important disputes:

(1) Green $v$. Miller, a federal case in Mississippi, at present on appeal to the Fifth Circuit. This concerns a school in Jackson, Mississippi, operated by the First Presby-

40. Brief for Defendants, New Jersey State Board of Higher Education v. Board of Directors of Shelton College (Superior Court of New Jersey, Chancery Division, Cape May County, Docket No. C-1088-79E, 1980), at pp. 39-41.

41. See the chronology in note 26 supra for an outline of the state action events in late fall, 1980.

42. New Jersey-Philadelphia Presbytery of the Bible Presbyterian Church v. New Jersey State Board of Higher Education, No. 79-3341 (D.N.J. May 18, 1981). 
terian Church. In 1979 the Internal Revenue Service tried to compel churchrelated schools to comply with certain regulations already enforced against statesupported schools. In particular, religious schools, on pain of being deprived of their tax-exemptions, were required to prove themselves innocent of racial discrimination by vigorous "affirmative action" and to submit their programs, staffs, and students to persons appointed by the Internal Revenue Service. The arguments advanced by the IRS are of interest. In effect, IRS declares that "national public policy" demands the end of all racial discrimination. Ball is endeavoring to intervene in this case on behalf of other Christian schools in Hattiesburg and Clarksdale; his motions to that effect have encountered strange difficulties in federal courts.

(2) State of Texas v. Roloff - a case that had to do with "charitable homes" operated by a church group. Brother Lester Roloff, a Baptist preacher, who runs halfway houses for alcoholics, runaways, drug addicts, parolees, probationers, and other folk in trouble, accepts no public funds. The Texas Department of Human Resources wanted to shut down Brother Roloff's Baptist hostels, which appear to be more effective than are parallel state institutions, on the ground that he would not seek state licenses. On the basis of church sponsorship of his "homes," Brother Roloff pointed to constitutional "entanglement" doctrine.

(3) State of Nebraska u. Miller, yet another case involving the Old Order Amish, who do not mean to send their children to public schools. At Pawnee City, Nebraska, Amish parents have been conducting their own grade school, without employing state-certified teachers.

(4) In Michigan, the state Board of Education brought suit against Sheridan Road Baptist Church and First Baptist Church at Bridgeport; these churches have appealed to the Michigan Circuit Court of Ingham County. This is the Shelton College case in another form and another state. Both churches operate Christian schools and do not submit to state supervision. A big trial is expected this summer: "The state is loaded for bear on this one," Ball comments. ${ }^{43}$

(5) One of the much-discussed cases concerning Bob Jones University, at Greenville, South Carolina, ${ }^{44}$ is an instance of the Internal Revenue Service seeking to terminate the tax exemption of the church-related institution, on the ground of the supremacy of public non-discrimination policy. The University, a thoroughly fundamentalist foundation, lost a recent round of this contest, when the Fourth Circuit Court of Appeals ruled in favor of IRS's "compelling interest" appeal. ${ }^{45}$ The administrators of Bob Jones University declare its right, as a religious institution, to expel students who cross "racial lines" in dating or marriage. Bob Jones has appealed to the Supreme Court, with the argument that no government interest of this sort can be so "compelling" as to transcend the constitutional provisions and precedents which separate church concerns and state concerns.

(6) In North Dakota, Pleasant Valley Christian School, operated by Mennonites,

43. Letter to author.

44. Bob Jones University v. United States, 468 F. Supp. 890 (D.S.C. 1978).

45. 639 F.2d 147 (4th Cir. 1980). 
has been threatened with closure by the public authorities-because of the state's teacher-certification statute. Ball drafted a bill ${ }^{46}$ for the North Dakota legislature that would have exempted religious schools from most state controls; but members of the legislature, allied with the state superintendent of public instruction, advanced a different bill that would substitute standardized testing for the teachercertification requirement. In North Carolina, the state, facing a threatened court injunction against a state testing program as applied to religious schools, has entered into a stipulation to abandon its effort at enforcement of such testing.

The above cases by no means exhaust Ball's private docket at the moment, and Ball is merely the most conspicuous of a good many lawyers specializing in churchstate cases. Other lawyers are engaged in a number of similarly vexing litigations. ${ }^{47}$ It must suffice to mention St. Martin Evangelical Lutheran Church v. South Dakota, concerning the attempt of the Department of Labor to collect unemployment taxes from church-related schools. This issue has been fought in various courts; the Court has now granted the petition for certiorari in the St. Martin case. ${ }^{48}$ The entanglement problem is conspicuous in the defendants' arguments: the church schools declare that the administration of such tax-collections would involve excessive surveillance of church schools by the state. ${ }^{49}$

More such cases will be in the courts before this article is published. Why are church-related colleges and schools seemingly in such a peck of troubles? Why are we hearing so much about "entanglement"? One reason-though not the major reason-for this flood of litigation is that church schools-heartened as much as a decade ago by the Burger "entanglement" test, and by the successes of Ball and other lawyers in Kentucky, Ohio, Wisconsin, and other states-have offered increasing resistance to the irksome interference of state departments of public instruction and of various federal agencies. Their refusal to submit to secular authorities parallels the increased activity of American evangelical Christians in practical politics; their confidence increases.

Friends to Christian schools were especially delighted with the 1979 decision of the Supreme Court of Kentucky in Kentucky State Board for Elementary and Secondary

46. House Bill 1608 and House Bill 1600 were both introduced in the latest session of the North Dakota Legislature. These bills, which were not successful, would have provided licensing exemptions to religious schools. In other states as well there have been endeavors to enact legislation to exempt religious schools from licensing. In Vermont such legislation is currently under consideration. In North Carolina a statute exempting religious schools from state regulation has been enacted. In Pennsylvania a bill which will exempt religious schools from state certification requirements will be introduced within the near future. These are but several examples, all supplied by Kathleen O'Malley, of the firm of Ball \& Skelly in Harrisburg, Pennsylvania.

47. There are summary descriptions of 87 cases concerning entanglement and other church-state concerns in Note, Recent Church and State Cases: A Summary, 24 ST. Lovis L.J. 425 (1980).

48. In the Matter of Northwestern Lutheran Academy, 290 N.W. 2d 845 (S.D. 1980), cert. granted sub nom. St. Martin Church v. South Dakota, 49 U.S.L.W. 3332 (U.S. Nov. 3, 1980) (No. 80-120). The petition was taken from St. Martin Evangelical Lutheran Church and Northwestern Lutheran Academy v. State of South Dakota, 290 N.W.2d 845 (1980).

49. This same question of whether parochial school personnel can be covered by the Federal Unemployment Tax Act, without excessive entanglement, has been considered by other courts with conflicting results. See the discussion in Serritella, supra note 3 , at text to notes 54-58. 
Education $v$. Rudasill-a case in which the defendants had been represented by Ball and Amshoff, a Louisville lawyer. ${ }^{50}$ Respective amicus curiae briefs in this appeal indicate the general alignment of forces in such church-school contests. ${ }^{51}$ For the plaintiffs were the Kentucky Association of School Administrators, the Kentucky State Education Association, and the Kentucky School Boards Association; for the defendant were the League of Catholic Parent-Teacher Associations of the Archdiocese of Louisville, the General Conference of Seventh-Day Adventists, and the Lutheran Education Ministries of Kentuckiana, Inc.

In Kentucky State Board, Kentucky's Supreme Court ruled unanimously that under the Kentucky Constitution no parent may be compelled to send his child to any school conscientiously repugnant to him; thus the criminal prosecution of parents who had enrolled their children in Christian schools unapproved by Kentucky's public-instruction authorities had to be abandoned by the state of Kentucky. This litigation had been undertaken with particular vehemence by the Kentucky educationists.

Church-related colleges and schools have been willing in a good many recent instances to litigate against state agencies, despite heavy required expenditures of money and time, precisely because of such examples of successful resistance as the Kentucky victory. Yet they have not acted without provocation; for a book might be written about the growth, in recent years, of hostility toward churches and churchrelated institutions among certain influential groups in the United States. It is not merely the Madalyn Murray O'Hair mentality which may be discerned in this development. It is rather the attitude of John Dewey's "Religious Humanist Manifesto," reaffirmed a few years ago by some eminent American secularists. ${ }^{52}$ That secular hostility is bound up with what Max Picard called "the world of the Flight" ${ }^{33}$ - that is, of the flight from God, who pursues.

This attitude may be called "disintegrated liberalism" or "ritualistic liberalism," of which one aspect is dread and suspicion of institutional Christianity - a kind of latter-day discipleship to Diderot and D'Alembert. It leads, in courts especially, to an interpretation of "separation" of church and state that means indifference or prohibition on the state's part. Sometimes this interpretation lies behind decisions of the Supreme Court, at least implictly - as illustrated by the Burger Court's ruling in late 1980 that the Kentucky superintendent of public instruction might not place copies of the Decalogue in that state's public-school classrooms. ${ }^{\mathbf{5 4}}$

As public schools become totally secularized by courts, Christian parents and parents of other religions naturally seek to maintain the doctrinal character of

50. Kentucky State Board for Elementary and Secondary Education v. Rudasill, 589 S.W.2d 877 (1979), cert. denied, - U.S. -, 48 U.S.L.W. 3733 (May 13, 1980).

51. For more information on alignments in amicus briefs, see another article in this issue, Amici in Church-State Litigation, by Leo Pfeffer, 44:2 Law \& Contemporary Prob. Spring 1981, 83-110.

52. The "Humanist Manifesto" of 1932 is reprinted in D. FABER (ed.), The Christian Challenge (Nov. 1980).

53. M. Picard, The Flight from God (1949).

54. Stone v. Sup't of Public Instruction of Kentucky, - U.S. -, 101 S. Ct. -, 66 L.Ed.2d 199 (1980). 
church-related schools: sanctuaries from crusading "humanists" (more accurately called "humanitarians"). On the one hand, Establishment Clause interpretation may be carrying entanglement to extremes, as in the Decalogue case. On the other hand, the Free Exercise Clause and/or non-entanglement under the Establishment Clause serves to protect church-related colleges and schools, in a good many instances, against state agencies that aspire to regulate them. The paradox may be structural. Certainly the Supreme Court and lesser courts often have been no more consistent in church-state decisions than they have been in rulings about pornography; conceivably the whole tendency of decisions in such cases might veer about.

The present Supreme Court understanding of "entanglement" and "separation of church and state" bears small resemblance to the germ of the Establishment and Free Exercise Clauses, as we find it in George Mason's sentences in the Virginia Declaration of Rights (1776):

That religion or the duty we owe to our Creator, and the manner of discharging it, being under the direction of reason and conviction only, not of violence or compulsion, all men are equally entitled to the free exercise of religion, according to the dictates of conscience, unpunished, and unrestrained by the magistrate, unless the preservation of equal liberty and the existence of the state are manifestly endangered. And that it is the mutual duty of all, to practice Christian forbearance, love and charity toward each other. ${ }^{55}$

For the time being, nevertheless, the current "entanglement" test, which might have seemed strange even to the tolerant George Mason, serves often as a shield to church-related institutions. Such colleges, schools, and other institutions have been increasing rapidly during the past two decades, especially among the religious fundamentalists. As they grow stronger and more numerous, it becomes more difficult for militant secularists and other adversaries to undo them.

I write "and other adversaries" because the pressure-groups working against religious schools have consisted of more than the people who look upon all religions as unfortunate vestigial survivals of the superstitions of the childhood of the human species. These are leagued with educational bureaucrats, dismayed at the rapid increase of enrollments in Christian schools, while public-school enrollments tend to decline. Educationists have a stake in discouraging religious schools. And we should not forget those curiously ideological officials of the Internal Revenue Service who suspect all Christian schools, especially in the South, of being masks for racism. The foes of religious schools are various. But just as all important differences of opinion at bottom are theological, so at bottom the opposition to religious schools is founded upon dislike of religious orthodoxy - and often upon desire to substitute for religious dogmata the dogmas of some political ideology. For a fuller development of this explanation, turn to $\mathrm{C}$. S. Lewis' little book The Abolition of Man. ${ }^{56}$

The Shelton College case illustrates well enough several of the points I suggest above. Why has the state of New Jersey so zealously pursued Shelton-at an

55. Va. Declaration of Rights, art. XVI (adopted June 6, 1776).

56. C. Lewis, The Abolition of Man (1947) 
expense, and with a pertinacity, unusual even in the prosecution of those crimes formerly called capital? What mischief is supposed to be worked by a half-dozen Bible Christian teachers, and a handful of earnest Bible Presbyterian boys and girls, that the state of New Jersey must pursue its "compelling interest" in their defeat and dispersal? In theory, America knows no establishment of religion; in actuality, one is tempted to suggest, we experience an establishment of Holy Public Educationism and Holy Secular Bureaucracy, particularly in New Jersey. James Madison, George Mason, and Fisher Ames, say, would have been startled and indignant, one suspects, at the state policy toward Shelton College and its tenacious Calvinists.

In Judge Gruccio's courtroom at Atlantic City, I thought on these things. All culture arises, in the beginning, from the cult. Without Christian culture and Christian hope, all the modern world would come to resemble a half-derelict fun fair, gone nasty and poverty-racked: in short, a universal Atlantic City. The managers of that dismal universe would be the sort of men and women who now run state departments of public instruction-and who do their best to make sure that no person and no institution rises conspicuously above mediocrity, or seriously challenges the assumptions of materialism, mechanism, "reductionism," and what Tocqueville called "democratic despotism." 5 ?

Entanglement! A good many Americans have entangled themselves, this past half-century or longer, in a web of illusions and half-truths about education, politics, and religion. The doctrine of a just separation of church and state is an old teaching, sound and true. "Two there are by whom this world is ruled," said Gelasius. ${ }^{58}$ Yet here is something worse than entanglement-so that, in the phrase of Philip Phenix, church and state would rot separately, in separate tombs. ${ }^{59}$ The faith of Shelton College is not my faith. Yet I am convinced that if we permit institutions like Shelton College to be harassed out of existence, we will have entangled ourselves in a misunderstanding of state and church as formidable as the great Serbonian bog, wherein whole armies have been swallowed up. The Secular City, having legislated and litigated itself out of any entanglement with the City of God, would be a hell upon earth.

57. A. de Tocqueville, What Sort of Despotism Democratic Nations Have to Fear, Democracy IN AMERICA 690-95 (J. P. Mayer ed. 1969).

58. See R. Niebuhr, The Structure of Nations and Empires, ch. VII (1959).

59. P. Phenix, Education and the Common Good: A Moral Philosophy of the Curriculum, ch 17 (1961). 